\title{
Standardized kinetic microassay to quantify differential chemosensitivity on the basis of proliferative activity
}

\author{
Günther Bernhardt, Herta Reile, Herbert Birnböck*, Thilo Spruß, and Helmut Schönenberger \\ Institut für Pharmazie, Sonderforschungsbereich 234, Universität Regensburg, W-8400 Regensburg, Federal Republic of Germany
}

Received 8 May 1991/Accepted 1 August 1991

Summary. Conventionally in vitro cytotoxicity assays are performed as single-end-point determinations. To compensate for the diversity of growth rates among different cell lines in this report we describe a computerized kinetic chemosensitivity assay based on quantification of biomass by staining cells with crystal violet. As a prerequisite four human breast cancer cell lines (MDA-MB-231, MCF-7, T-47-D and ZR-75-1) were characterized with regard to oestrogen and progesterone receptor content, modal chromosome number and proliferation kinetics depending on the number of passages in culture. With prolonged time in culture for ZR-75-1 exposed to various concentrations of cisplatinum a dose-related increase in drug effect was observed. Owing to a correction of the $\mathrm{T} / \mathrm{C}$ values for the initial cell mass (at the time when drug is added) a sharp distinction between cytostatic and cytocidal drug effects becomes obvious in plots of corrected $\mathrm{T} / \mathrm{C}$ values versus time of incubation. The influence of the untreated control on the corrected $\mathrm{T} / \mathrm{C}$ values and possible time courses of theoretical inhibition profiles (reflecting cytostatic, transient cytotoxic or cytocidal drug effects as well as development of resistance) and their relationship to the corresponding growth curves of drugtreated cells are discussed. Chemosensitivity assays with diethylstilbestrol dipropionate, tamoxifen, melphalan, cisplatinum, vinblastine, Adriamycin and 5-fluorouracil prove the theoretical considerations to be true for MDAMB-231, MCF-7, T-47-D and ZR-75-1 human breast cancer cell lines in practice.

Key words: Crystal violet chemosensitivity assays Microtitration plates - Human breast cancer cell lines Proliferation kinetics - Anticancer drug effects

\footnotetext{
* Present address: F. Hoffmann-La Roche AG, Grenzacher Strasse 124, CH-4002 Basel, Switzerland

Abbreviations: PBS, phosphate-buffered saline; FCS, fetal calf serum; NCS, newborn calf serum; ER, oestrogen receptors; PR, progesterone receptor

Offprint requests to: G. Bernhardt, Pharmazeutische Chemie II, Universität Regensburg, Universitätsstrasse 31, W-8400 Regensburg, FRG
}

\section{Introduction}

Within the drug-development programme of the National Cancer Institute (NCI) the models used to select new drugs for the clinic have changed periodically over the years (Venditti 1981; Goldin et al. 1979). Strategies have been based largely upon the in vivo testing of agents in mice bearing transplantable leukemias and solid murine tumours. Such a screening system was composed of a highly sensitive "prescreen", the P388 leukemia model, and a "tumour panel" composed of three transplantable murine cancers, the L1210 lymphocytic leukemia, the B16 melanoma, and the M5076 sarcoma; and a human mammary tumour xenograft, the MX-1 (Venditti 1983).

Since no perfect non-human model of human cancer could be found, most recently the NCI is implementing a new anticancer drug-screening programme using a disease-oriented panel of cultured human tumour cell lines for the initial stages of screening (Shoemaker et al. 1985; Alley et al. 1988; Scudiero et al. 1988; Paull et al. 1989). This in vitro/in vivo concept differs from previous in vivo systems in two fundamental ways: (a) a single in vivo murine leukemia "prescreen" step (P388) has been replaced by broad-based evaluation among a wide variety of cell lines; and (b) the major clinical forms of solid tumours are represented by panels of well-defined human tumour cell lines. Agents showing differential or selective patterns of in vitro growth inhibition will be evaluated subsequently in athymic mice bearing the same human tumour cell lines found sensitive in vitro.

For the in vitro evaluation of antineoplastic agents on a wide variety of cultured tumour cell lines (Carmichael et al. 1987) microculture techniques are extensively in use, since "monolayer" methods probably offer the greatest flexibility in terms of possible drug exposure and recovery conditions. As a consequence the experimental protocols are very heterogeneous, depending on the special requirements and characteristics of a particular cell line under investigation.

Vital parameters that vary between different assays include: inoculum density, culture conditions, duration 
of drug exposure, duration of the recovery period after drug exposure, and the nature of the end-point used to quantify drug effects (Alley et al. 1988; Scudiero et al. 1988; Roper and Drewinko 1976; Finlay and Baguley 1984; Reddel and sutherland 1987). Therefore interassay comparison, evaluation and interpretation of drug action on the basis of median inhibitory concentrations $\left(\mathrm{IC}_{50}\right.$ values) from data collected among different cell lines are extremely difficult or impossible.

In contrast to the MTT [3-(4,5-dimethylthiazol-2-yl)2,5-diphenyltetrazolium bromide] assay, which is based on metabolic activity, the crystal violet technique measures the total dye-binding capacity of a given cell population, thus correlating with biomass.

Since drugs can show quite different inhibitory effects dependent on the parameters mentioned above, a new kinetic approach to chemosensitivity testing based on a standardized microculture crystal violet assay (Gillies et al. 1986; Kueng et al. 1989; Reile et al. 1990; Müller et al. $1990)$ is presented in this publication.

\section{Materials and methods}

Chemicals. Reagents (A-grade purity) were obtained from Merck (Darmstadt, FRG). $N$-Hexamethylpararosaniline (crystal violet) was purchased from Serva (Heidelberg, FRG). The scintillation liquid Quickszint 212 was obtained from Zinsser Analytic (Frankfurt, FRG), $N, N$-dimethylformamide, spectrophotometric grade, from Aldrich (Steinheim, FRG). Fetal calf serum (FCS) and newborn calf serum (NCS) were from Gibco (Eggenheim, FRG). Millipore-filtered water was used throughout.

Cell lines and routine culture conditions. All cell lines were obtained from the American Type Culture Collection (ATCC) (Rockville, Md., USA). Cell line banking and quality control were performed according to the "seed stock concept" reviewed by Hay (1988). All culture media contained $50 \mathrm{mg} / 1$ gentamycin (Sebio, Walchsing, FRG).

MDA-MB-231 (ATCC no. HTB 26), a human adenocarcinoma of the breast (Cailleau et al. 1974), was maintained in McCoy's 5A medium (Boehringer, Mannheim, FRG) containing L-glutamine, $\mathrm{NaHCO}_{3}(2.2 \mathrm{~g} / 1)$, and $10 \% \mathrm{NCS}$.

The MCF-7 (ATCC no. HTB 22) human breast cancer cell line (Soule et al. 1973) was maintained in Eagle's minimum essential medium (Sigma, München, FRG) containing L-glutamine, $\mathrm{NaHCO}_{3}$ $(2.2 \mathrm{~g} / 1)$, sodium pyruvate (Sigma, München, FRG) $(110 \mathrm{mg} / \mathrm{l})$, and $10 \%$ FCS.

T-47-D (ATCC no. HTB 133) a human ductal adenocarcinoma of the breast, established from pleural effusion (Keydar et al. 1979), was grown in RPMI-1640 medium (Sigma, München, FRG) containing L-glutamine, $\mathrm{NaHCO}_{3}(2.2 \mathrm{~g} / 1)$, and $10 \% \mathrm{FCS}$. The culture medium was supplemented with $10 \mathrm{mg} / \mathrm{l}$ bovine insulin (Sigma, München, FRG).

The ZR-75-1 (Engel et al. 1978) human breast cancer cell line (ATCC no. CRL-1500) was cultivated in RPMI-1640 medium (Sigma, München, FRG) containing L-glutamine, $\mathrm{NaHCO}_{3}(2.2 \mathrm{~g} / 1)$, and $10 \%$ FCS.

The cells were serially passaged weekly following trypsinization using trypsin $(0.05 \%) /$ EDTA $(0.02 \%)$ (Boehringer, Mannheim, FRG) and cultured in a water-saturated atmosphere of $95 \%$ air and $5 \%$ carbon dioxide at $37^{\circ} \mathrm{C}$ in $75-\mathrm{cm}^{2}$ flasks (Falcon Plastics 3023 , Heidelberg, FRG). Cells were routinely monitored for, and shown to be free of, Mycoplasma contamination (Peters and Baumgarten 1990).

Growth characteristics. Proliferation kinetics and doubling times were determined by a computer-aided crystal violet procedure, which has been described recently (Reile et al. 1990).
Cytogenetic analysis. The cells were grown to about $50 \%$ confluence on microscopic slides. The slides were prepared as described elsewhere (Rooney and Czepulkowski 1986). In order to inhibit spindle formation, the slide chambers were inoculated with colcemid solution (Serva, Heidelberg, FRG) to a final concentration of $0.04 \mu \mathrm{g}$ / $\mathrm{ml}$ and incubated for $3 \mathrm{~h}$ at $37^{\circ} \mathrm{C}$. The medium was removed by suction and replaced with $0.075 \mathrm{M} \mathrm{KCl}$. After $30 \mathrm{~min}$ incubation at $37^{\circ} \mathrm{C}$ an equal volume of cold, freshly made fixative (absolute methanol/glacial acetic acid 3:1) was added. This hypotonic/fixative mixture was removed immediately and replaced twice with ice-cold, fresh fixative. The slides were removed from the dish and air-dried. The chromosomes were stained for $8 \mathrm{~min}$ with $10 \mathrm{ml}$ Giemsa stain plus $90 \mathrm{ml} 0.025 \mathrm{MKH}_{2} \mathrm{PO}_{4}, \mathrm{pH} 6.8$.

The chromosome number of 50 well-spread metaphases was determined using an Olympus BH-2 microscope with a $60 \times$ SPlanApo (oil) objective (Olympus Optical Co. Ltd., Tokyo, Japan). The microscopic image was focused through a NFK $2.5 \times$ photoeyepiece to a Panasonic F10 CCD videocamera (Matsushita Communication Industrial Co. Ltd., Osaka, Japan). For image analysis the video signal was transformed in a PIP-512/1024A video digitizer board (Matrox Electronic Systems Ltd., Quebec, Canada) installed in an Olivetti M24 personal computer (Ivrea, Italy) and visualized on a Sony PVM-1371 QM video monitor (Tokyo, Japan). The chromosomes were marked with a mouse and automatically counted using an image-processing programme written in TURBO PASCAL.

Oestrogen and progesterone receptor assay. Total cellular oestrogen receptor (ER) and progesterone receptor (PR) levels were measured simultaneously using a HPLC micromethod. The procedure described by Formento et al. (1987) was adopted with modifications (Birnböck 1988; v. Angerer et al. 1989). Confluent cultures (cells from three $75-\mathrm{cm}^{2}$ flasks) were harvested with $0.02 \%$ EDTA and centrifuged at $1000 \mathrm{~g}$ for $10 \mathrm{~min}$ at $0^{\circ} \mathrm{C}$. After two cycles of washing with PBS $\left(8.0 \mathrm{~g} / 1 \mathrm{NaCl}, 0.2 \mathrm{~g} / 1 \mathrm{KCl}, 0.2 \mathrm{~g} / 1 \mathrm{KH}_{2} \mathrm{PO}_{4}, 1.0 \mathrm{~g} / 1\right.$ $\left.\mathrm{Na}_{2} \mathrm{HPO}_{4} \cdot 2 \mathrm{H}_{2} \mathrm{O}, 0.15 \mathrm{~g} / 1 \mathrm{NaH}_{2} \mathrm{PO}_{4} \cdot \mathrm{H}_{2} \mathrm{O}\right)$ and centrifugation the cell pellet was shock-frozen and stored at $-80^{\circ} \mathrm{C}$. For cytosol preparation the pellets were resuspended in $0.5-1.0 \mathrm{ml}$ phosphate-buffered saline (PBS). The cells were disrupted by sonication (10 bursts, step 5) (type G 15 sonifier; Branson Sonic Power Co., Danburg, Conn.) at $0^{\circ} \mathrm{C}$. Proteases were inhibited by the addition of $1 \mathrm{mM}$ phenylmethylsulfonyl fluoride (Sigma, München, FRG). The completeness of cell lysis was controlled by microscopic observation. For the simultaneous determination of ER and PR two solutions were prepared: (I) $18 \mathrm{n} M\left[{ }^{3} \mathrm{H}\right] \mathrm{R} 2858$ (New England Nuclear, Dreieich, FRG), $18 \mathrm{n} M\left[{ }^{3} \mathrm{H}\right] \mathrm{ORG} 2058$ (Amersham, Braunschweig, FRG), $3.6 \mu M$ cortisol, $3.6 \mu \ddot{M}$ diethylstilbestrol (Sigma, München, FRG) in TEDG buffer, containing $10 \mathrm{~m} M$ TRIS/HCl, $1 \mathrm{~m} M$ EDTA, $0.5 \mathrm{~m} M$ dithiothreitol (Sigma, München, FRG), $10 \mathrm{~m} M$ sodium molybdate, $20 \%$ (v/v) glycerol, pH 7.4; (II) $18 \mathrm{nM}$ $\left[{ }^{3} \mathrm{H}\right] \mathrm{R} 2858, \quad 18 \mathrm{n} M \quad\left[{ }^{3} \mathrm{H}\right] \mathrm{ORG} 2058,3.6 \mu M$ cortisol, $3.6 \mu M$ ORG2058 (Amersham Buchler, Braunschweig, FRG) in TEDG buffer. Incubation of aliquots of the cytosols with solution I reveals non-specific binding to ER and total binding to PR, whereas incubation with solution II reveals total binding to $E R$ and non-specific binding to PR. Specific binding of each of the two different tracers can be calculated by subtracting non-specific from total binding. The analysis was performed according to $v$. Angerer et al. (1989). At a flow rate of $1.0 \mathrm{ml} / \mathrm{min}$ (methanol/water, $80: 20 \mathrm{v} / \mathrm{v}$ ) the $t_{\mathrm{R}}$ intervals for $\left[{ }^{3} \mathrm{H}\right] \mathrm{R} 2858$ were $2.7-4.3 \mathrm{~min}$, for $\left[{ }^{3} \mathrm{H}\right]$ ORG2058 $5.1-$ $6.4 \mathrm{~min}$ and for $\left[{ }^{14} \mathrm{C}\right]$ oestrone (Amersham Buchler, Braunschweig, FRG) 4.2-5.5 $\mathrm{min}$.

Determination of cytosolic protein. Soluble protein was measured using the bicinchoninic acid method described for microtitre plates (Smith et al. 1985; v. Angerer et al. 1989).

Drugs. Cisplatinum (gold label) was obtained from Aldrich (Steinheim, FRG). Melphalan, diethylstilbestrol dipropionate, tamoxifen (citrate salt) and 5-fluorouracil were purchased from Sigma (München, FRG), Adriamycin (doxorubicin hydrochloride with carrier lactose) and vinblastine (sulphate) from Serva (Heidelberg, FRG). Except for cisplatinum and melphalan, all drugs were dis- 
solved in $70 \%(\mathrm{v} / \mathrm{v})$ ethanol. Cisplatinum solution was prepared in dimethylformamide, melphalan solution in $70 \%$ ethanol containing $0.35 \%(\mathrm{v} / \mathrm{v})$ hydrochloric acid. After appropriate dilution the drugs were added to culture medium such that the final ethanol concentration was $0.07 \%$, the final dimethylformamide concentration $0.1 \%$ $(\mathrm{v} / \mathrm{v})$.

Chemosensitivity assay. The procedure described by Gillies et al. (1986) was modified and optimized for microculture conditions (Reile et al. 1990). For chemosensitivity testing the cells were seeded $(100 \mu 1 /$ well) in 96-well flat-bottomed microtitration plates (Falcon Plastics 3075, Heidelberg, FRG) at an appropriate density of approximately 15 cells/microscopic field (Leitz, Diavert, $320 \times$ ). After $48 \mathrm{~h}$ the medium was carefully removed by suction and replaced by fresh medium $(200 \mu \mathrm{l} /$ well) containing drugs (drugs were added as a 1000-fold concentrated stock solution) or pure solvent. On every plate the rows 5 and $6(n=16)$ served as controls, whereas two vertical rows $(n=16)$ per drug concentration were used. The cultures were not refed during chemosensitivity testing, since the exchange of the culture medium prolonged the lag phase of the cultures. However, no influence on the growth characteristics caused by the properties of the organic solvent (dimethylformamide and ethanol) was observed. After various times of incubation the culture medium was shaken off and the cells were fixed with $100 \mu 11 \%$ glutardialdehyde in PBS/well for $15 \mathrm{~min}$. The fixative was replaced by $150 \mu \mathrm{PBS} /$ well and the plates were stored in the refrigerator $\left(4^{\circ} \mathrm{C}\right)$. At the end of the experiment all trays were stained simultaneously with $0.02 \%$ aqueous crystal violet solution $(100 \mu \mathrm{l} /$ well $)$ for $30 \mathrm{~min}$. Excess dye was removed by rinsing the trays with water for $15 \mathrm{~min}$. The stain bound by the cells was redissolved in $70 \%$ ethanol $(180 \mu \mathrm{l} /$ well) while shaking the microplates for $2-4 \mathrm{~h}$ on a Köttermann 4010 shaker (Köttermann, Hänigsen, FRG). Absorbance was measured at $578 \mathrm{~nm}$ using a Biotek 309 Autoreader (Tecnomara, Fernwald, FRG). The readings were directly transferred to an Olivetti M 24 (Ivrea, Italy) personal computer and saved on a diskette.

Quantification of drug action. Corresponding absorbance measurements were identified, grouped according to the experimental layout (usually $n=16 /$ group) and corrected for outliers at a confidence level of $P=0.05$. The confidence limits were adjusted according to

$\left|x_{i}-X\right| \leqq 2 \cdot \sigma(X)$

where $x_{i}$ is the $i$-th value of the data set and $X$ is the mean of the data set.

After the removal of outliers, the mean and standard deviation of grouped values were recalculated. Typical intraexperimental coefficient of variation (CV) values were found to be between $3 \%$ and $7 \%$. Mean values that showed a $\mathrm{CV}>10 \%$ were marked and excluded from further evaluation.

Drug effects were expressed as corrected $\mathrm{T} / \mathrm{C}$ values for each group according to

$(\mathrm{T} / \mathrm{C})_{\mathrm{corr}}(\%)=A_{\mathrm{T}}-A_{\mathrm{c}, 0} / A_{\mathrm{c}}-A_{\mathrm{c}, 0} \cdot 100$

where $A_{\mathrm{I}}$ is the mean absorbance of the treated cells, $A_{\mathrm{c}}$ the mean absorbance of the controls and $A_{c, 0}$ the mean absorbance at the time $(t=0)$ when drug was added.

The significance of the corrected $\mathrm{T} / \mathrm{C}$ values was verified by performing an analysis of variance based on the assumption of a $t$-distribution (Sokal and Rohlf 1987).

The variances of the $\mathrm{T} / \mathrm{C}$ values were calculated from the known variances of the $A_{\mathrm{T}}, A_{\mathrm{c}}$ and $A_{\mathrm{c}, 0}$ values according to the general error law:

Let

$f\left(A_{\mathrm{T},}, A_{\mathrm{c}}, A_{\mathrm{c}, 0}\right) \equiv(\mathrm{T} / \mathrm{C})_{\mathrm{corr}}$

Therefore,

$\operatorname{var}(f)=\left(\mathrm{d} f / \mathrm{d} A_{\mathrm{T}}\right)^{2} \cdot \operatorname{var}\left(A_{\mathrm{T}}\right)+\left(\mathrm{d} f / \mathrm{d} A_{\mathrm{c}}\right)^{2} \cdot \operatorname{var}\left(A_{\mathrm{c}}\right)$ $+\left(\mathrm{d} f / \mathrm{d} A_{\mathrm{c}, 0}\right)^{2} \cdot \operatorname{var}\left(A_{\mathrm{c}, 0}\right)$.

Results were printed in tabulated from ready for further evaluation (see Reile et al. 1990).

\section{Results}

Characterization of the cell lines used in chemosensitivity studies

Steroid receptor content. In addition to routine microbiological and morphological quality control, oestrogen and progesterone receptor contents, karyotype and growth characteristics were periodically monitored.

The steroid receptor content of the cell lines used are listed in Table 1. Both ER and PR concentrations differ substantially among cell lines. Whereas MDA-MB-231 is clearly negative for both steroid receptors, the receptor content of MCF-7, T-47-D and ZR-75-1 varies extremely with the passage. Shortly after rethawing, the ER concentration of MCF-7 cells (in passage 154) was at the limits of detection, whereas their PR content was $39 \mathrm{fmol} / \mathrm{mg}$. In passage 166 a drastic increase in $\mathrm{ER}(119 \mathrm{fmol} / \mathrm{mg})$ with concomitant decrease $(8 \mathrm{fmol} / \mathrm{mg}$ ) of PR was observed. Whereas the ER and PR contents of ZR-75-1 increased with prolonged time in culture, for both ER and PR no trend was discernible in T-47-D.

Table 1. Steroid receptor content of four human breast cancer cell lines in early plateau phase

\begin{tabular}{lccc}
\hline Cell line & $\begin{array}{l}\text { Passage } \\
\text { from } \\
\text { origin }\end{array}$ & $\begin{array}{l}\text { Oestrogen } \\
\text { receptor } \\
\text { (fmol/mg) }\end{array}$ & $\begin{array}{l}\text { Progesterone }^{\text {a }} \\
\text { receptor } \\
\text { (fmol/mg) }\end{array}$ \\
\hline MDA-MB-231 & 32 & $3(2)$ & $1(1)$ \\
MCF-7 & 37 & $2(2)$ & $7(2)$ \\
& 154 & $2(2)$ & $39(9)$ \\
T-47-D & 166 & $119(18)$ & $8(1)$ \\
& 177 & $148(13)$ & $5(2)$ \\
& 90 & $22(1)$ & $1(1)$ \\
& 93 & $14(10)$ & $98(4)$ \\
ZR-75-1 & 96 & $8(2)$ & $37(1)$ \\
& 98 & $4(1)$ & $46(1)$ \\
& 109 & $22(10)$ & $69(2)$ \\
& 87 & $2(1)$ & $4(1)$ \\
& 89 & $2(2)$ & 0 \\
& 104 & $13(2)$ & $21(9)$
\end{tabular}

a fmol receptor/mg soluble protein; mean of three determinations (standard deviation in parentheses)

Table 2. Karyology of four human breast cancer cell lines used in this study

\begin{tabular}{lcll}
\hline Cell line & $\begin{array}{l}\text { Passage } \\
\text { from } \\
\text { origin }\end{array}$ & & \multicolumn{2}{c}{ Chromosome number } \\
\cline { 3 - 4 } & 27 & Modal & Range \\
\hline MDA-MB-231 & 36 & 60 & $53-116$ \\
MCF-7 & 169 & 60 & $55-185$ \\
T-47-D & 98 & 82 & $40-166$ \\
& 111 & 64 & $58-115$ \\
ZR-75-1 & 92 & 63 & $39-103$ \\
& 130 & 74 & $27-77$ \\
& & 75 & $33-77$ \\
\hline
\end{tabular}


Genetic stability. Modal chromosome numbers and ranges for the human breast cancer cell lines in different passages are summarized in Table 2.

Although differing from published values (Finlay and Baguley 1984), the modal chromosome numbers of MDA-MB-231, MCF-7 and T-47-D remained stable over the observed culture period. The modal chromosome number (74-75) of the ZR-75-1 cell line is identical with the values reported for passage 38 in the original publication (Engel et al. 1978). In the case of severe structural or numerical chromosome aberrations, cryopreserved stock cultures have to be used for further assays.

Growth characteristics. Growth characteristics differ between cell lines (Fig. 5). For MDA-MB-231 the minimal doubling time was $40 \mathrm{~h}$, for MCF-7 $45 \mathrm{~h}$, for T-47-D $56 \mathrm{~h}$ and for ZR-75-1 $84 \mathrm{~h}$.

Figure 1 illustrates how with prolonged time in culture the minimal doubling times may change in unpredictable ways (Finlay and Baguley 1984; Reile et al. 1990) even when inoculation density and culture conditions were kept constant.

\section{Kinetic crystal violet chemosensitivity assay}

Figure 2 summarizes the effect of $0.5,1.0$ and $5.0 \mu M$ cisplatinum on ZR-75-1 cells incubated for $333 \mathrm{~h}$. After various times of incubation for six different end-points, the corrected $\mathrm{T} / \mathrm{C}$ values were determined by the crystal violet procedure. Although a clear-cut dose/response relationship was observed for all end-points, it is apparent that the corrected $\mathrm{T} / \mathrm{C}$ values continuously decreased with prolonged time in culture. Owing to the instability of cisplatinum under culture conditions (full activity retained for $6 \mathrm{~h}$; complete loss at $48 \mathrm{~h}$; Wilson 1986), the changes in $T / C_{\text {corr }}$ primarily do not seem to be directly related to drug incorporation during prolonged time of treatment.

Figure 3 shows a diagrammatic representation of typical data obtained by the kinetic crystal violet chemosensitivity assay based on the determination of the reproductive potential of a drug-treated culture. The relationship between growth kinetics of treated cell populations on one hand, and a plot of corrected $\mathrm{T} / \mathrm{C}$ values versus time of incubation on the other, is illustrated in Fig. $3 \mathrm{~A}$, B. In the following, drug effects are presented as plots of corrected $\mathrm{T} / \mathrm{C}$ values versus time of incubation. The correction for the initial cell number (at the time when drug is added) allows discrimination between cytostatic and cytocidal drug action at any time of incubation.

\section{Differential chemosensitivity \\ of the human breast cancer cell lines $M D A-M B-231$, $M C F-7, T-47-D$, and $Z R-75-1$ to selected anti-tumour agents}

Since there was no significant difference between dimethylformamide and ethanol, only the growth characteristics

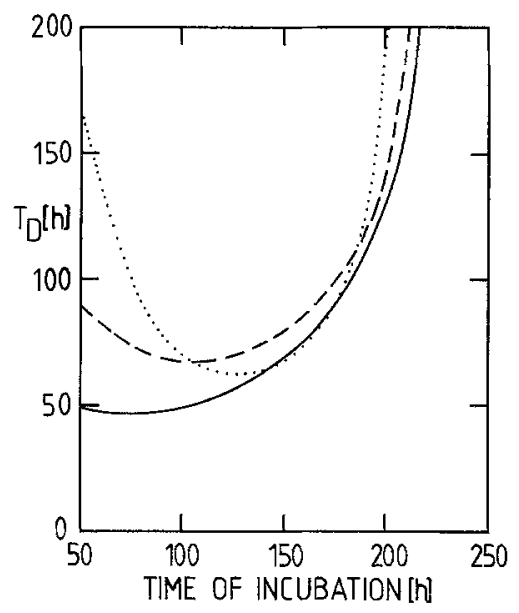

Fig. 1. Variation of doubling time $\left(T_{D}\right)$ with the number of passage. The growth characteristics of MCF-7 controls (the culture medium contained $0.1 \%$ dimethylformamide) from different chemosensitivity tests are shown. Culture conditions and the cell density of the inoculum were identical. _-, 155th; ---, 169th; ..., 194th passage from origin

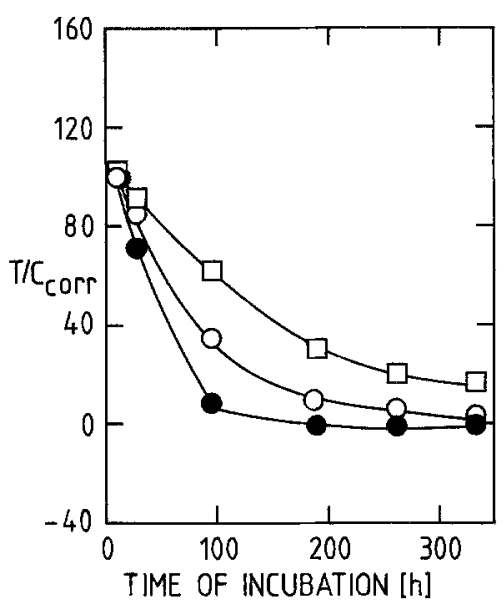

Fig. 2. Inhibitory effect of cisplatinum on the proliferation of human ZR-75-1 breast cancer cells as a function of incubation time determined by the crystal violet assay. Cells in passage 93 were treated with () $0.5 \mu M$ (o) $1 \mu M$ and (•) $5 \mu M$ cisplatinum

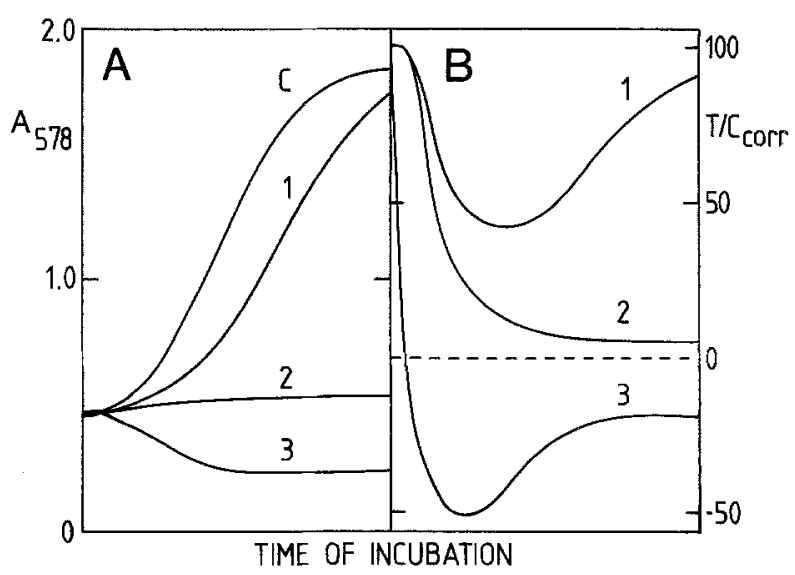

Fig. 3. Schematic diagram of the interrelationship between growth curves $(\mathbf{A})$ and corrected $\mathrm{T} / \mathrm{C}$ profiles $(\mathbf{B})$ illustrating the in vitro response of cells to treatment with chemotherapeutics. $C$, Proliferation kinetics of the untreated control. 1, The population completely recovers after initial damage (cytotoxic drug effect). 2, Cell proliferation is inhibited (cytostatic drug effect). 3, The profiles represent the disintegration of the cells (cytocidal drug effect) 

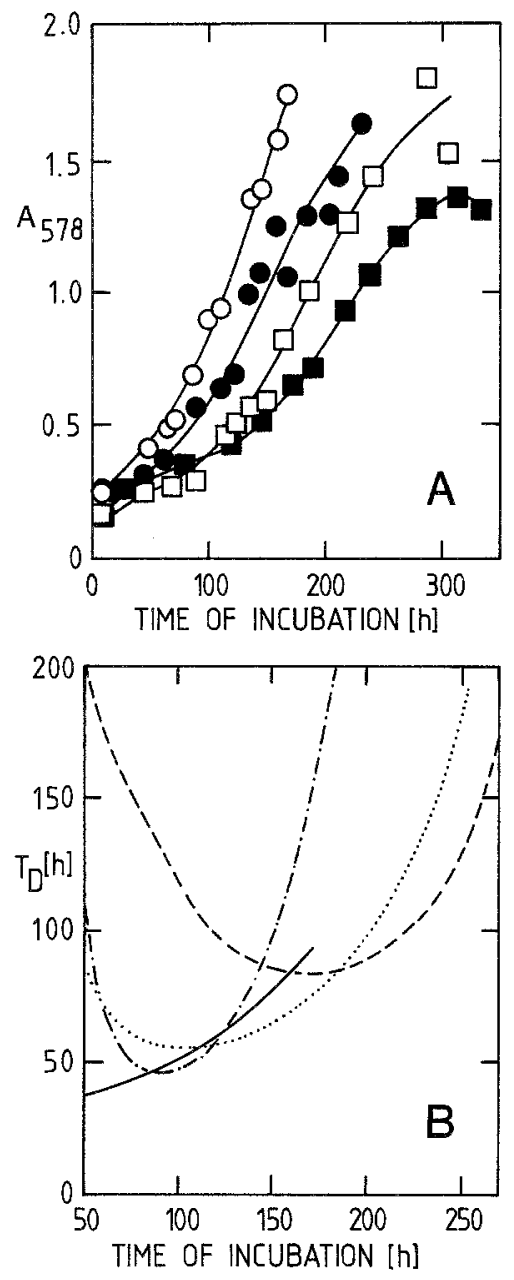

Fig. 4A, B. Growth characteristics of the untreated controls (culture medium contained $0.07 \%$ ethanol) from the following chemosensitivity assays. In order to obtain higher resolution time intervals are closely scattered. Therefore, in all experiments in addition to the obligatory controls on every microtitration plate (rows 5 and 6 ) several microplates were incubated under control conditions. At the time points indicated the cells were fixed with glutardialdehyde and processed simultaneously with the trays from the chemosensitivity assay at the end of the experiment. From these control growth curves and the data from the corresponding corrected $\mathrm{T} / \mathrm{C}$ profiles any growth curve of a drug-treated cell population can be reconstructed according to Eq.2. A Growth curves. $\square$, T-47-D, passage 105; $\mathbf{n}$, ZR-75-1, passage 93; O, MDA-MB-231; passage 35; $\bullet$, MCF-7, passage 168 . B Corresponding doubling times $\left(T_{D}\right)$ as a function of incubation time...., T-47-D, passage 105; ---, ZR-75-1, passage 93; -, MDA-MB-231, passage 35;---, MCF-7, passage 168

of the controls containing the vehicle ethanol are depicted in Fig. 4.

According to Eq. 2, any growth curve of a drugtreated cell population can be reconstructed from the $\mathrm{T} /$ $\mathrm{C}_{\text {corr }}$ profile (Figs. 5-8) and the growth curve of the corresponding control (Fig. 4A).

Response to hormonal therapy. None of the breast cancer cell lines investigated was inhibited by $10 \mathrm{n} M$ diethylstilbestrol (Fig. 5A). On the contrary, cell proliferation of MCF-7, T-47-D and ZR-75-1 was stimulated to a certain extent. Stimulation became obvious after about $100 \mathrm{~h}$ of incubation. This effect $\left(167 \% \mathrm{~T} / \mathrm{C}_{\text {corr }}\right.$ for $\mathrm{ZR}-75-1$ after
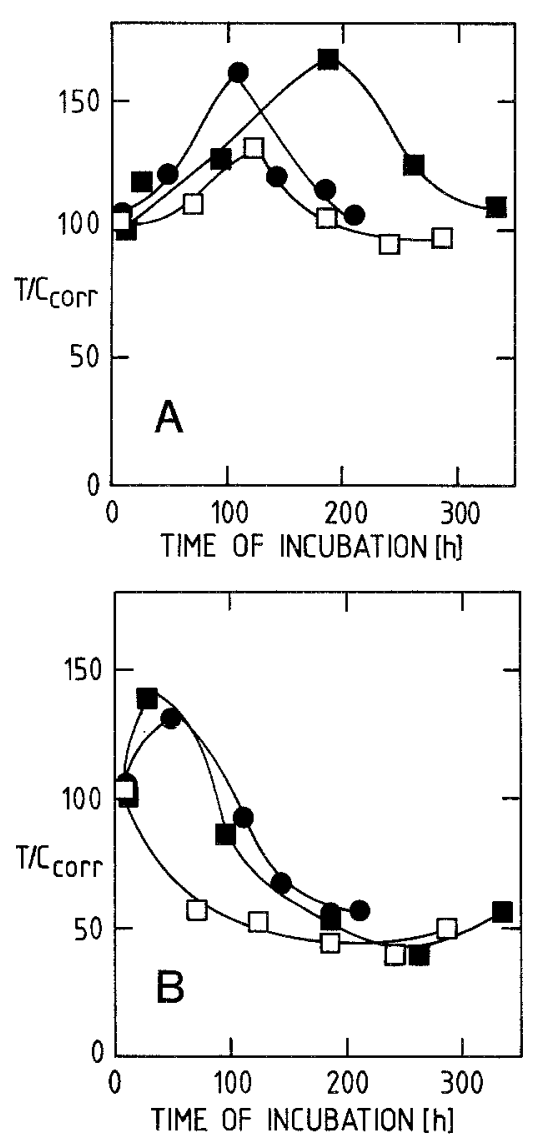

Fig. 5 A, B. In vitro effect of hormonal therapy on human breast cancer cell lines. $\square$, T-47-D, passage 105; n, ZR-75-1, passage 93; $\bullet$, $\mathrm{MCF}-7$, passage 168. A $10 \mathrm{n} M$ diethylstilbestrol dipropionate. $\mathrm{B}$ $0.5 \mu M$ tamoxifen; MDA-MB-231 was not influenced by tamoxifen concentrations up to $10 \mu M$

$189 \mathrm{~h}$ ) was transient. At the end of the assay all cell lines regained a $\mathrm{T} / \mathrm{C}_{\text {corr }}$ value of about $100 \%$. Figure $5 \mathrm{~B}$ shows the effect of $0.5 \mu M$ tamoxifen. MCF-7, T-47-D and ZR75-1 were inhibited with a minimal $\mathrm{T} / \mathrm{C}_{\text {corr }}$ value of around $40 \%$. As discussed for curve 1 in Fig. 3, all three cell lines recovered towards the end of the experiment. Cell proliferation of MDA-MB-231 was not affected by tamoxifen concentrations up to $10 \mu M$ (data not shown).

Sensitivity to alkylating agents. The effect of $1 \mu M$ melphalan and $1 \mu M$ cisplatinum is shown in Fig. 6A, B. Dramatic differences in sensitivity to melphalan were detectable. ZR-75-1 was transiently stimulated and a final $\mathrm{T} / \mathrm{C}_{\text {corr }}$ of $89 \%$ was reached after $333 \mathrm{~h}$ of incubation. Melphalan was cytostatic to MDA-MB-231 and MCF-7 whereas T-47-D regained proliferative integrity after slight initial impairment by $1 \mu M$ melphalan.

Cisplatinum $(1 \mu M)$ was cytostatic to ZR-75-1 and MCF-7. MDA-MB-231 and T-47-D recovered after initial damage.

Sensitivity to natural products. Chemosensitivity to $1 \mathrm{n} M$ vinblastine is presented in Fig. $7 \mathrm{~A}$. Although initially inhibited by the alkaloid, ZR-75-1 recovered (cf. Fig. 3, curve 1) with a $T / C_{\text {corr }}$ value of around $60 \%$. For $T-47-D$ 

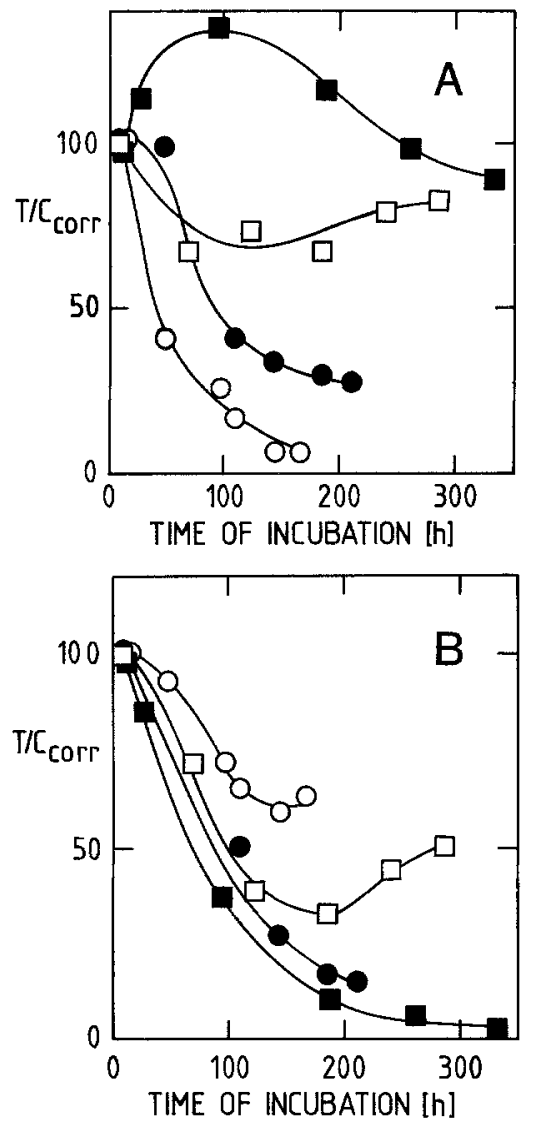

Fig.6A,B. Chemosensitivity of human breast cancer cell lines against alkylating agents. $\square, T-47-D$, passage 105; $\mathbf{m}, Z R-75-1$, passage 93 ; O, MDA-MB-231, passage 35 ; $\bullet$ MCF-7, passage 168 . A $1 \mu M$ melphalan; B $1 \mu M$ cisplatinum

the $\mathrm{T} / \mathrm{C}_{\text {corr }}$ curve showed a similar time course but the inhibitory effect of vinblastine was less pronounced, and the culture recovered almost completely. Likewise MDAMB-231 and MCF-7 were initially inhibited. The trend of the graphs to parallel the time axis while the corresponding controls (cf. Fig. 4A) still exhibit relatively high proliferation rates indicates the tendency of the cultures to recover. Vinblastine at $0.1 \mu M$ was cytocidal to MCF-7, ZR-75-1 and T-47-D and cytostatic to MDA-MB-231 (data not shown).

Adriamycin (1 $\mu M$, see Fig. 7 B) was cytocidal to all four cell lines (data for MDA-MB-231 are not shown).

Effect of the antimetabolite 5-fluorouracil. At $1 \mu M, 5-$ fluorouracil (Fig. 8) exerted a cytostatic effect on ZR-751 and T-47-D. In comparison to cisplatinum (Fig. 6B) the manifestation of drug action was delayed. Cell proliferation of MDA-MB-231 and MCF-7 was only slightly affected.

\section{Discussion}

The presence of measurable amounts (usually $>10 \mathrm{fmol} /$ mg cytosolic protein) of both ER and PR is associated with the highest response rate to hormonal treatment. Tumours lacking both receptors rarely respond. ER-
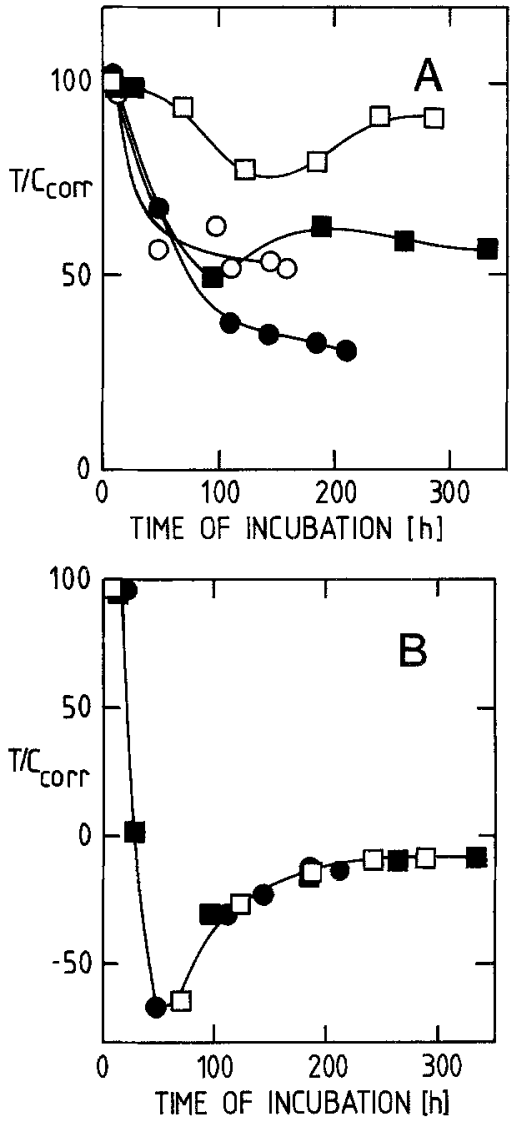

Fig. 7A,B. Chemosensitivity of human breast cancer cell lines against natural products. $\square$, T-47-D, passage 105; $\mathbf{~ , ~ Z R - 7 5 - 1 , ~ p a s - ~}$ sage 93 ; O, MDA-MB-231, passage 35 ; $\bullet$, MCF-7, passage 168 . A $1 \mathrm{n} M$ vinblastine; $\mathrm{B} 1 \mu M$ Adriamycin

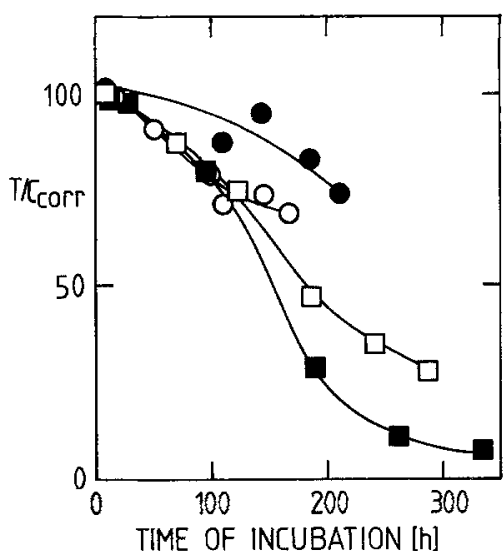

Fig. 8. Effect of $1 \mu M$ 5-fluorouracil on the human breast cancer cell lines: $\square$, T-47-D, passage 105; $\mathbf{m}$, ZR-75-1, passage 93; O, MDAMB-231, passage 35; $\bullet$ MCF-7, passage 168

positive tumours that recur following hormonal manipulation tend to have low or absent ER levels (Canellos 1985). Spontaneous evolution of several distinct sublines and clones of T-47-D with marked differences in ER and PR contents under identical culture conditions has been reported recently (Reddel et al. 1988).

Owing to this dramatic variability, periodical control of the steroid receptor state (ideally parallel to chemosensitivity testing) is essential. 
Since ER is heterogeneously distributed in different cell clones of a breast tumour, the additional semiquantitative immunohistochemical determination and intracellular localization of the receptor could be useful.

To overcome the problem of genetic instability of tumour cells (Whang-Peng et al. 1983; Yunis 1983) in testing anticancer drugs by cell culture techniques, chromosome analysis is indispensable.

The determination of growth kinetic curves by the crystal violet method is very easy to perform, because compared to the tetrazolium-based assay - immediate and complete processing and measurement of the microplates after various times of incubation are not essential. For an optimal design of chemosensitvity assays the knowledge of the beginning and duration of the logarithmic growth phase is essential. This can be easily obtained from a diagram plotting the doubling time versus the time of incubation where, under these conditions, the graph parallels the $x$-axis.

Although it is generally claimed that chemosensitivity testing is performed with exponentially growing populations it must be pointed out that for all cell lines examined, the exponential growth phase is restricted to maximally two generations. Exponentiality assumes that the growth rate and doubling time are both fixed constants, a situation that is rarely encountered either in vivo or in culture (Skehan 1986). In fact, most mammalian cells in culture exhibit nonexponential growth, i.e. the growth rate and doubling time change continuously (Skehan and Friedman 1984; Reile et al. 1990), and there is no single value of either that can be used to characterize the growth of a system. Although Freshney et al. (1975) previously indicated that $\mathrm{IC}_{50}$ values are influenced by the density of plated cells and decrease continuously with increasing time of drug exposure, thus reflecting an increase in drug sensitivity, still most chemosensitivity assays are performed as single-end-point determinations (Skehan et al. 1990; Rubinstein et al. 1990). Whereas an increase in the duration of the exposure to a drug frequently increased the sensitivity, no change or decrease in chemosensitivity occurred with time in culture. The alterations observed are caused, on the one hand, by specific properties of the drugs and, on the other hand, by the nature of the assay used to quantify the drug effect.

Cytotoxicity assays measure drug-induced alterations in metabolic pathways (MTT assay) or structural integrity (e.g. ${ }^{51} \mathrm{Cr}$ release or dye exclusion), which may or may not be directly related to cell death. In contrast, survival (reproductive integrity) assays measure the end result of such metabolic perturbations, which may lead either to cell recovery or cell death.

Conventionally drug effects are compared on the basis of uncorrected $\mathrm{T} / \mathrm{C}$ (or resulting $\mathrm{IC}_{50}$ ) values, which means that the initial cell density (at the time when drugs are added) is not taken into account. Especially when alterations of $A_{578}$ are small compared with the absorbance of the initial cell density, this practice results in pronounced underestimation of inhibitory drug effects. The correction of the $\mathrm{T} / \mathrm{C}$ values has the advantage that only net changes in biomass are evaluated. As a consequence, inhibitory effects can be clearly distinguished from cytocidal drug action.
The time course of the growth curve of the untreated control is of extreme importance because of its direct influence on the $\mathrm{T} / \mathrm{C}$ values. Therefore, its determination with precise discrimination between the lag, log, and plateau phases is a must.

$\mathrm{T} / \mathrm{C}_{\text {corr }}$ decreases as long as the treated cells ( $\mathrm{T}$ ) grow more slowly than the untreated control (C). While the control cells enter the plateau-phase as growth comes to a standstill, $\mathrm{T} / \mathrm{C}_{\mathrm{corr}}$ stagnates or increases.

When the absorbance of the treated cells remains unchanged (cytostatic drug effect), as shown in curve 2, T/ $\mathrm{C}_{\text {corr }}$ is characterized by a steep initial decrease until a constant value, determined by the absorbance of the treated cells and the absorbance of the controls at saturation density, is reached and maintained.

The effects of cytotoxic substances may appear in different ways, for example, when the culture is toxically damaged shortly after the addition of the drug but during the course of the experiment completely recovers, i.e. it regains full reproductive integrity and finally reaches the saturation density of the untreated control (curve 1). Possible reasons for such behaviour (depending on the particularities of the tumour cell line and the biochemical target of the drug) are:

1. Inactivation of the drug in the culture medium or metabolism into less active compounds

2. Only a fraction of the cell population being killed; the non-lethally damaged (metabolic impair) population recovers

3. Development of secondary resistance.

In all cases, $\mathrm{T} / \mathrm{C}_{\text {corr }}$ continuously decreases as long as $\mathrm{C}$ grows faster than $\mathrm{T}$ and remains constant when the proliferation rates of $\mathrm{T}$ and $\mathrm{C}$ are identical. The following increase in $T / C_{\text {corr }}$ is caused by a relative acceleration of cell proliferation of $\mathrm{T}$ compared to $\mathrm{C}$, which enters the plateau phase. When enough time of incubation is provided, a final $\mathrm{T} / \mathrm{C}_{\text {corr }}$ of $100 \%$ will be obtained as soon as $T$ reaches the saturation density of $C$.

On the other hand, the exposure of tumour cells to toxic agents (curve 3 ) may result in cell death accompanied by cell lysis (cytocidal drug effect). As cells die, the absorbance of the treated culture wells is lower than the absorbance of the culture at the time when drug was added. Since the initial absorbance is subtracted, $\mathrm{T} / \mathrm{C}_{\text {corr }}$ becomes negative when the lysing cells outnumber the proliferating cell population. As long as the plateau phase is not reached by $\mathrm{C}, \mathrm{T} / \mathrm{C}_{\mathrm{corr}}$ increases for arithmetic reasons. The final numerical value is determined by the absorbance of $\mathrm{T}$ and $\mathrm{C}$ corrected for the initial cell mass. $A$ second intersection of the $T / C_{\text {corr }}$ versus time graph with the time axis is usually not observed. A transition of the curve from negative to positive values theoretically indicates revival of the culture.

Although the plot of the corrected $\mathrm{T} / \mathrm{C}$ values versus time clearly represents cytocidal drug action, the corrected $\mathrm{T} / \mathrm{C}$ ratio is not appropriate for precisely quantifying net cell killing. When the absorbance of treated cells $\left(A_{\mathrm{T}}\right)$ is less than that of the culture at $t=\mathrm{O}\left(A_{\mathrm{c}, 0}\right)$ the extent of cell killing must be calculated as $100 \cdot\left(A_{\mathrm{T}}-A_{\mathrm{c}, 0} /\right.$ $A_{\mathrm{c}, 0}$ (cf. Skehan et al. 1986).

This specific assay is applicable to any adherently growing cell type and allows for a quantitative compari- 
son of structural drug analogues, as well as alternative experimental dosage formulations.

Figures 5-8 clearly demonstrate that the theoretical considerations discussed in Fig. 3 are proved true in practice. This study emphasizes the great variation in the intrinsic responses of cell lines to a group of clinically used agents as a function of incubation time. To compensate for the diversity of growth rates among different cell lines, in our opinion a kinetic approach to chemosensitivity testing should be sought. Although for preliminary large-scale screening single-end-point determinations may be sufficient, for more detailed investigations of drug action the kinetic assay procedure is preferable because it provides unambiguous information concerning differential sensitivity and, in addition, potential development of resistance is readily observed from one single experiment.

In order to improve in vitro/in vivo correlation, chemical stability and pharmacokinetic parameters (concentration of free drug and time of exposure) of the drugs to be tested should be taken into account. The choice of drug concentrations should be dictated by considerations of the therapeutic levels that can be achieved with clinically used drug dosages dependent on scheduling. The kinetic approach presented in this publication offers the great advantage of combining and coordinating a variety of different antitumour drugs (new and clinically established) according to their inhibition ( $\mathrm{T} / \mathrm{C}_{\text {corr }}$ versus time) profiles.

This method, particularly developed for the in vitro evaluation of the activity of potential anticancer drugs, incorporates the desirable features of simplicity, reproducibility and sensitivity. The kinetic assay procedure can be easily adopted to the sulphorhodamine B procedure currently favoured by the NCI (Skehan et al. 1990; Rubinstein et al. 1990).

In our opinion, the application of this kinetic assay to compounds (selected by conventional screening) could be of great value in revealing specific properties of drugs or special peculiarities of different tumour types, resulting in improved predictibility of in vivo drug effects.

Acknowledgements. This work was supported by the Deutsche Forschungsgemeinschaft and the Matthias-Lackas-Stifung für Krebsforschung. Thanks are due to the Fonds der Chemischen Industrie for financial support. We thank P. Pistor for excellent technical help and F. Birk for helpful assistance in developing the image analysis system. We are grateful to Prof. Dr. R. Jaenicke for critical reading of the manuscript and $R$. Schlemmer for stimulating discussion.

\section{References}

Alley MC, Scudiero DA, Monks A, Hursey ML, Czerwinski MJ, Fine DL, Abbott BJ, Mayo JG, Shoemaker RH, Boyd MR (1988) Feasibility of drug screening with panels of human tumor cell lines using a microculture tetrazolium assay. Cancer Res 48:589-601

Angerer E v, Birnböck H, Knebel N (1989) Platinum complexes with a selective action on estrogen receptor-positive mammary tumors. Anti-Cancer Drug Design 4:21-35

Birnböck H (1988) Untersuchungen zur Pharmakokinetik des Zindoxifens und zur Wirkung von Inhibitoren der Steroidsulfatase an hormonabhängigen Tumoren. Thesis, Universität Regensburg

Cailleau R, Young R, Olivé M, Reeves WJ (1974) Breast tumor cell lines from pleural effusions. J Natl Cancer Inst 53:661-673

Canellos GP (1985) Carcinoma of the breast. In: Wyngaarden JB, Smith LH (eds) Cecil textbook of medicine, 17 th edn. Saunders, Philadelphia, pp 1402-1405

Carmichael J, DeGraff WG, Gazdar AF, Minna JD, Mitchell JB (1987) Evaluation of a tetrazolium-based semiautomated colorimetric assay; assessment of chemosensitivity testing. Cancer Res 47:936-942

Engel LW, Young NA, Tralka TS, Lippman ME, O'Brien SJ, Joyce MJ (1978) Establishment and characterization of three new continous cell lines derived from human breast carcinomas. Cancer Res 38:3352-3364

Finlay GJ, Baguley BC (1984) The use of human cancer cell lines as a primary screening system for antineoplastic compounds. Eur $\mathrm{J}$ Cancer Clin Oncol 20:947-954

Formento J-L, Moll J-L, Francoual M, Krebs BP, Milano G, Renee N, Khater R, Frenay M, Namer M (1987) HPLC micromethod for simultaneous measurement of estradiol, progesterone, androgen and glucocorticoid receptor levels. Application to breast cancer biopsies. Eur J Cancer Clin Oncol 23:1307-1314

Freshney RI, Paul J, Kane IM (1975) Assay of anti-cancer drugs in tissue culture; conditions affecting their ability to incorporate ${ }^{3} \mathrm{H}$-leucine after drug treatment. Br J Cancer 31:89-99

Gillies RJ, Didier N, Denton M (1986) Determination of cell number in monolayer cultures. Anal Biochem 159:109-113

Goldin A, Schepartz SA, Venditti JM et al. (1979) Historical development and current strategy of the National Cancer Institute drug development program. In: DeVita VT, Busch $\mathbf{H}$ (eds) Methods in cancer research: XVI. Academic Press, New York, pp 165-245

Hay RJ (1988) The seed stock concept and quality control for cell lines. Anal Biochem 171:225-237

Keydar I, Chen L, Karby S, Weiss FR, Delarea J, Radu M, Chaitcik $S$, Brenner HJ (1979) Establishment and characterization of a cell line of human breast carcinoma origin. Eur J Cancer 15:659670

Kueng W, Silber E, Eppenberger U (1989) Quantification of cells cultured on 96-well plates. Anal Biochem 182:16-19

Müller R, Gust R, Bernhardt G, Keller C, Schönenberger H, Seeber S, Osieka R, Eastmann A, Jennerwein M (1990) D,L-[1,2-Bis(2hydroxyphenyl)ethylenediamine]dichloroplatinum(II), a new compound for the therapy of ovarian cancer. J Cancer Res Clin Oncol 116:237-244

Paull KD, Shoemaker RH, Hodes L, Monks A, Scudiero DA, Rubinstein L, Plowman J, Boyd MR (1989) Display and analysis of patterns of differential activity of drugs against human tumor cell lines: development of mean graph and COMPARE algorithm. J Nat1 Cancer Inst 81:1088-1092

Peters JH, Baumgarten H (1990) Monoklonale Antikörper: Herstellung und Charakterisierung. Springer, Berlin, pp 124-129

Reddel RR, Sutherland RL (1987) Effects of pharmacological concentrations of estrogens on proliferation and cell cycle kinetics of human breast cancer cell lines in-vitro. Cancer Res 47:53235329

Reddel RR, Alexander IE, Koga M, Shine J, Sutherland RL (1988) Genetic instability and the development of steroid hormone insensitivity in cultured T 47D human breast cancer cells. Cancer Res 48:4340-4347

Reile H, Birnböck H, Bernhardt G, Spruß Th, Schönenberger H (1990) Computerized determination of growth kinetic curves and doubling times from cells in microculture. Anal Biochem 187:262-267

Rooney DE, Czepulkowski BH (eds) (1986) Human cytogenetics, a practical approach. IRL, Oxford, p 10

Roper PR, Drewinko B (1976) Comparison of in vitro methods to determine drug-induced cell lethality. Cancer Res 36:21822188

Rubinstein LV, Shoemaker RH, Paull KD, Simon RM, Tosini S, Skehan P, Scudiero DA, Monks A, Boyd MR (1990) Compari- 
son of in vitro anticancer-drug screening data generated with a tetrazolium assay versus a protein assay against a diverse panel of human tumor cell lines. J Natl Cancer Inst 82:1113-1118

Scudiero DA, Shoemaker RH, Paull KD, Monks A, Tierney S, Nofziger TH, Currens MJ, Seniff D, Boyd MR (1988) Evaluation of a soluble tetrazolium/formazan assay for cell growth and drug sensitivity in culture using human and other tumor cell lines. Cancer Res 48:4827-4833

Shoemaker RH, Wolpert-DeFilippes MK, Kern DH, Lieber MM, Makuch RW, Melnick NR, Miller WT, Salmon SE, Simon RM, Venditti JM, Von Hoff DD (1985) Application of a human tumor colony-forming assay to new drug screening. Cancer Res $45: 2145-2153$

Skehan P (1986) On the normality of growth dynamics of neoplasms in vivo: a data base analysis. Growth 50:496-515

Skehan P, Friedman SJ (1984) Nonexponential growth by mammalian cells in culture. Cell Tiss Kinet 17:335-343

Skehan P, Thomas J, Friedman SJ (1986) Postconfluency MDCK monolayers as an in vitro model of solid tumor chemosensitivity. Cell Biol Toxicol 2:357-368

Skehan P, Storeng R, Scudiero D, Monks A, McMahon J, Vistica D, Warren JT, Bokesch H, Kenney S, Boyd MR (1990) New colorimetric cytotoxicity assay for anticancer-drug screening. J Natl Cancer Inst 82:1107-1112
Smith PK, Krohn RI, Hermanson GT, Mallia AK, Gartner FH, Provenzano MD, Fujimoto EK, Goeke NM, Olsen BJ, Klenk DC (1985) Measurement of protein using bicinchoninic acid. Anal Biochem 150:76-85

Sokal RR, Rohlf FJ (1987) Introduction to Biostatistics, 2nd edn. Freeman, New York, pp 133-184

Soule HD, Vazques J, Long A, Albert S, Brennan M (1973) A human cell line from a pleural effusion derived from a breast carcinoma. J Natl Cancer Inst 51:1409-1416

Venditti JM (1981) Preclinical drug development: rationale and methods. Semin Oncol 8:349-361

Venditti JM (1983) The National Cancer Institute antitumor drug discovery program, current and future perspectives: a commentary. Cancer Treat Rep 67:767-772

Whang-Peng J, Lee EC, Kao-Shan C-S, Seibert K, Lippman M (1983) Cytogenetic studies of human breast cancer lines: MCF-7 and derived variant sublines. J Natl Cancer Inst 71:687-695

Wilson AP (1986) Cytotoxicity and viability assays. In: Freshney RI (ed) Animal cell culture, a practical approach. IRL Press, Oxford, pp 191-216

Yunis JJ (1983) The chromosomal basis of human neoplasia. Science 221:227-236 